\title{
Synthesis of yeast cell wall glucan and evidence for glucan metabolism in a Saccharomyces cerevisiae whole cell system
}

\author{
Michael L. Coen, Claude G. Lerner, John O. Capobianco \\ and Robert C. Goldman \\ Author for correspondence: Robert C. Goldman. Tel: +1 708937 4477. Fax: +1 7089386603.
e-mail: goldmanr@,randb.abbott.com
}

Anti-infective Research Division, Abbott Laboratories, Abbott Park, IL 60064-3500, USA

\begin{abstract}
The synthesis and metabolism of yeast cell wall glucan were studied using a Saccharomyces cerevisiae construct in which radiolabelled galactose is metabolized to UDP-glucose and preferentially incorporated into glucan. Greater than $85 \%$ of the incorporated radiolabel was found within insoluble cell wall material. Our study also demonstrated that radiolabelled wall glucan is released from cells growing exponentially, and that the released radiolabel is reutilizable low molecular mass material. Size exclusion chromatography and enzymic analysis indicate that laminaribiose comprises approximately $50 \%$ of the released fraction. This is consistent with in vitro findings that laminaribiose is a by-product of a newly identified glucosyltransferase (R. P. Hartland, G. W. Emerson \& P. A. Sullivan, 1991, Proc R Soc Lond B 246, 155-160) associated with fungal cell walls. Our results also suggest that pre-existing glucan undergoes less metabolic processes than newly synthesized material as evidenced by a decrease in released radiolabel over time. Pulse double labelling of glucan and total cellular protein indicate that glucan metabolism and protein synthesis (ps) are not tightly coupled although they do parallel each other during exponential growth. Inhibitors of glucan synthesis (gs) decrease the glucan to protein ratio. Measurement of ps allows normalization for non-specific decreases in the rate of cell wall synthesis due to general cessation of growth. Cilofungin and papulacandin B, two putative inhibitors of gs, inhibited galactose incorporation into glucan and thus showed a decrease in the glucan to protein ratio, although ps was affected. In contrast, cycloheximide, a known ps inhibitor, displayed an elevated ratio. This whole cell construct affords a simplified system for elucidating the synthesis and metabolic activity of the yeast cell wall and enables the discrimination between specific effectors of gs and ps.
\end{abstract}

Keywords: Saccharomyces cerevisiae, glucan metabolism, yeast cell wall, whole cell system

\section{INTRODUCTION}

Compared to bacteria, little is known about cell wall synthesis, assembly, and metabolism in yeast and other fungi. It is generally believed that the yeast cell wall undergoes many essential metabolic events during growth and maturation. De novo synthesis of cell wall components (Hector, 1993), cell wall restructuring and modification during morphogenesis (Wessels et al., 1990) and in response to external stimuli (Ruiz-Herrera, 1992), and selective degradation (Hector, 1993) of wall materials are presumed to be important processes in cell growth. The yeast cell wall consists of an inner electron-transparent layer composed of intertwined glucan and chitin fibrils surrounded by an outer dense layer predominately composed of mannoprotein (Ruiz-Herrera, 1992). Covalent cross-linkages between these components may exist, i.e. glucan and chitin (Gooday et al., 1992; Gopal et al., 1984; Shepherd et al., 1984; Sietsma \& Wessels, 1981, 1979; Surarit et al., 1988) or glucan and/or chitin and mannoprotein (Beaudouin et al., 1993; Peberdy, 1990). More detailed reviews of yeast cell wall structure can be found elsewhere (Cabib et al., 1991, 1982; Peberdy, 1990; RuizHerrera, 1992; Wessels et al., 1990). Many membrane- and 
wall-associated enzymes have been identified and their catalytic activity with regard to the cell wall structural elements characterized. Among them are $\beta$-glucan and chitin synthetases (Peberdy, 1990), endo- and exo- $\beta$ glucanases (Chambers, 1993; Klebl \& Tanner, 1989; Mrsa et al., 1993), endochitinases (Gooday et al., 1992; Hien \& Fleet, 1983), and glucosyltransferases (P. A. Sullivan, personal communication). Characterization of these enzyme activities, the enzymic sequences, and the consequences of the multitude of metabolic events involved within the yeast cell wall architecture remain the topic of intense investigation.

Glucan is the most abundant structural polymer of the cell wall of all yeasts and fungi. Yeast glucan is composed of glucose oligomers having $(1,3)-\beta$ and $(1,6)-\beta$ configurations (Peberdy, 1990, Ruiz-Herrera, 1992). Synthesis of fungal glucan can be studied in vitro using isolated microsomes; however, technical constraints have made it difficult to study wall glucan metabolism in vivo. To date, analysis of glucan synthesis has been hampered by cumbersome methodologies which involve cell breakage, harsh extraction conditions, or both (Ruiz-Herrera, 1992). Three different types of glucan have been identified from yeast cell walls (Fleet \& Manners, 1976; Manners $e t$ al., 1973a, b; Peberdy, 1990; Shepherd et al., 1984) but it is not proven whether these three species are distinguishable within the intact cell or their separation is simply an artifact of the harsh extraction procedures employed. Following the initial synthesis of glucan there are likely post-synthetic processing/restructuring events which occur at various points within the cell cycle. Such events likely occur during bud emergence, hyphal branching, wall expansion, cell separation, spore formation and germination (Kurranda \& Robbins, 1991 ; Peberdy, 1990; Ruiz-Herrera, 1992; San Segundo et al., 1993; Wessels et al., 1990) but are poorly understood.

In the present study a simplified whole cell model for assessing glucan biosynthesis and metabolism was developed utilizing a Saccharomyces cerevisiae construct which allows selective double labelling of cell wall glucan and cellular protein. The resultant genetic manipulations afford a method for specific labelling of glucan with radiolabelled galactose rather than glucose. Inhibition of synthesis of either of the major carbohydrate polymers (glucan or chitin) is detrimental to fungal cell survival; however, the affects of blocking morphological rearrangements or assembly of these polymers into the wall structure are presently unknown. Cilofungin (a derivative of echinocandin B) and papulacandin B are members of two chemical groups which inhibit glucan synthesis by an unknown mechanism of action (Cabib et al., 1991). Additionally, many azole and polyene compounds used as antifungal agents have effects on numerous plasma membrane enzymes including those involved in glucan synthesis (Surarit \& Shepherd, 1987). No definitive studies have been conducted on the effects of such agents on the synthetic rates of glucan versus total cellular protein. Advantages of this system are: (i) enzymes involved in glucan synthesis (gs) and protein synthesis (ps) remain in their natural state; (ii) rates of gs and ps are simultaneously monitored by direct TCA precipitation; (iii) cell supernatants can be easily analysed for byproducts (metabolites) of gs; and (iv) the effect of putative inhibitors of gs and ps and the metabolism of cell wall glucan can be studied in detail using pulse double labelling techniques. We present in vivo evidence for the metabolism and subsequent release of cell wall glucan oligosaccharides and using inhibitors investigated the coupling between gs and ps.

\section{METHODS}

Yeast strains and plasmids. The parent Saccharomyces cerevisiae strain, Sc488 (a ura3-52 leu2-3, 112 ade 1 gal80 bxk2::UR A3) and plasmid pBM34BX-HD (source of GAL5) were kindly provided by Dr James E. Hopper (Department of Biological Chemistry, The Milton S. Hershey Medical Center, The Pennsylvania State University, Hershey, PA, USA). Plasmid Ep146 (source of LEU2, $A p^{\mathrm{R}}$ ) was kindly provided by Dr Alan Hinnebusch (NIH, Bethesda, MD, USA). Plasmid pB34BX-LD (source of gal5) used for insertional inactivation of the major phosphoglucomutase $(P G M 2=G A L 5)$ isoenzyme was constructed by ligation of the LEU2 gene into the pBM34BX-HD vector and selected for ampicillin resistance in Eschericia coli DH5a. Briefly, the plasmid vector, pBM34BX-HD, was linearized and the LEU2 gene excised from plasmid Ep146 by restriction enzyme digestion with HindIII. The fragments were purified by agarose gel electrophoresis and ligated with T4 ligase. E. coli was transformed by standard methods and colonies selected for ampicillin resistance (Maniatis et al., 1982). Plasmids were isolated and confirmed by HindIII digestion and agarose gel electrophoresis. The plasmid pBM34BX-LD was restriction digested with $X b o \mathrm{I}$ and $B a m \mathrm{HI}$ to yield a $4.5 \mathrm{~kb}$ fragment containing the LEU2 gene flanked by GAL5 sequences. The parent strain Sc488 was transformed with the resulting digest mixture by a modified lithium acetate method (Ito $e t$ al., 1983). The transformed construct Sc488-11 A (a ade1 leu2-3, 112 ura 3 52 gal80 gal5::LEU2 bxk2::UR A3) was selected by leucineindependent growth. The phenotypes of all yeast strains were verified by growth on specific media. The $b \times k 22$ inactivation and leucine auxotrophy in the parent strain Sc 488 were confirmed by growth on galactose as the sole carbon source, uracil-independent growth, and leucine-independent growth, respectively. PGM2 (gal5) inactivation in construct Sc488-11A was confirmed by the inability to grow on galactose as the sole carbon source and leucine-independent growth.

Culture conditions. All strains were grown and maintained on YPD medium (Difco) containing $40 \mu \mathrm{g}$ adenine $\mathrm{ml}^{-1}$ (YPAD) at $30{ }^{\circ} \mathrm{C}$. Sc488-11A labelling experiments were carried out in yeast nitrogen base minimal media $(1 \times$ YNB with amino acids $+\left(\mathrm{NH}_{4}\right)_{2} \mathrm{SO}_{4} ;$ Difco) containing $2 \%(\mathrm{w} / \mathrm{v})$ glucose and $40 \mu \mathrm{g}$ adenine $\mathrm{ml}^{-1}$ in a $30^{\circ} \mathrm{C}$ shaking water bath unless otherwise noted. OD was measured at a wavelength of $420 \mathrm{~nm}$. The mean generation time of Sc488-11A growing in YNB containing $2 \%$ glucose as described above was determined to be approximately $2 \cdot 1 \mathrm{~h}$ during mid-exponential growth.

Chemicals. $\mathrm{D}-\left[1-{ }^{14} \mathrm{C}\right]$ galactose $\left(50-60 \mathrm{mCi} \mathrm{mmol}^{-1}\right.$, catalogue no. CFA. $\left.435 ; 1 \mathrm{Ci}=3.7 \times 10^{10} \mathrm{~Bq}\right)$ and $\mathrm{L}-\left[4,5-{ }^{3} \mathrm{H}\right]$ leucine (120-190 Ci mmol ${ }^{-1}$, catalogue no. TRK.636) used for double radiolabelling experiments, and $\mathrm{D}-\left[6-{ }^{3} \mathrm{H}\right]$ galactose $(20-40 \mathrm{Ci}$ $\mathrm{mmol}^{-1}$, catalogue no. TRK.651) used for glucan release experiments were obtained from Amersham, Arlington Heights, IL, USA. $\left[{ }^{3} \mathrm{H}\right]$ Laminaribiose $\left(250 \mathrm{mCi} \mathrm{mmol}^{-1}\right)$ was prepared by enzymic hydrolysis and isolated by column chromatography by John Capobianco and Dorothy Zakula at 
Abbott Laboratories, Abbott Park, IL, USA. Briefly, $\beta$ - $(1,3)$ $\left[{ }^{3} \mathrm{H}\right]$ ylucan was prepared enzymically from UDP-D-[6$\left.{ }^{3} \mathrm{H}\right]$ glucose (13 $\mathrm{Ci} \mathrm{mmol}^{-1}$, catalogue no. TRK.385) and Candida albicans microsomes as described by Frost et al. (1992). The radiolabelled glucan was digested with zymolyase $100 \mathrm{~T}$ and the hydrolvtic products were separated by Sephadex G-50 (Pharmacia, Uppsala, Sweden) column chromatography. The radicactive oligosaccharides migrating in the included volume were recovered by lyophilization, and laminaribiose was then purified by HPLC on a $4.6 \mathrm{~mm} \times 25 \mathrm{~cm}$ Dynamax-60A $\mathrm{NH}_{2}$ column (Rainin Instruments) run in acetonitrile/water $(1: 1)$. Zymolvase $100 \mathrm{~T}$ and laminarioligosaccharides were obtained from Seikagaku America Inc. Cilofungin was obtained from Eli Lilly. Papulacandin B was obtained from Ciba-Geigy. Cycloheximide and all other reagents were obtained from Sigma and were of the highest possible grade. The minimal inhibitory concentrations (MIC) for cilofungin, papulacandin $\mathrm{B}$, and cycloheximide in strain Sc488-11A are $50 \mu \mathrm{g} \mathrm{ml}^{-1}, 2.5 \mu \mathrm{g} \mathrm{ml}$, and $39 \mathrm{ng} \mathrm{ml}^{-1}$, respectively, as determined by microtitre broth dilution. In duplicate, compounds were twofold serially diluted to a final volume of $50 \mu \mathrm{l}$ medium per well. A culture was grown, as described, to an $\mathrm{OD}_{420}=0 \cdot 4$, diluted $1: 50$ in medium, and $50 \mu \mathrm{l}$ added to each well. Growth inhibition was recorded after overnight incubation at $32{ }^{\circ} \mathrm{C}$. MIC values are defined as the lowest drug concentrations necessary for complete grow th inhibition with a control well reaching maximal density.

Radiolabel distribution analysis. Sc488-11A was continuously labelled with $2 \mu \mathrm{Ci} \quad\left[{ }^{14} \mathrm{C}\right]$ galactose $\mathrm{ml}^{-1}$ and $1 \mathrm{mg}$ galactose carrier $\mathrm{ml}^{-1}$ to an approximate $\mathrm{OD}_{420}=3 \cdot 0$. Cells were broken by vortexing with an equal volume of $500 \mu \mathrm{m}$ diameter glass beads previously acid washed and rinsed in $0.01 \mathrm{M}$ ammonium acetate buffer, $\mathrm{pH} 5 \cdot 6$. The buffer-insoluble cell walls were resuspended in $10 \mathrm{mM}$ Tris $/ \mathrm{HCl}, \mathrm{pH} 7 \cdot 5$, containing $2 \%(\mathrm{w} / \mathrm{v})$ SDS and heated to $100^{\circ} \mathrm{C}$ for $5 \mathrm{~min}$ to solubilize mannoprotein (Valentin et al., 1984). Samples of buffer-insoluble, SDS-washed walls were treated with $\alpha$-amylase, proteinase $\mathrm{K}$ or zymolyase, respectively, and analysed for released radioactive counts. The $\beta-(1,3)$ and $\beta-(1,6)$ linkage ratio was estimated by zymolyase digestion and size separation by Sephadex G-25 (Pharmacia) column chromatography. Zymolyase-100T contains predominantly $\beta$ - $(1,3)$-glucan laminaripenta-hydrolase in addition to significant activities of $\beta$ - $(1,3)$-exoglucanase, protease and mannanase. All of the soluble supernatants resulting from the above digestions were TCA-precipitated, after which any TCAsoluble material was ethanol-precipitated. Radioactive counts were quantified in a Wallac 1410 liquid scintillation counter (Pharmacia).

Continuous double radiolabelling of glucan and protein. An Sc488-11 A culture $(20 \mathrm{ml})$ was grown to early exponential phase (approx. $\mathrm{OD}_{420}=1 \cdot 0$ ), at which time labelling $\mathrm{mix}[10 \mu \mathrm{g}$ leucine $\mathrm{ml}^{-1}, 1 \mathrm{mg}$ galactose $\mathrm{ml}^{-1}, 5 \mu \mathrm{Ci}\left[{ }^{3} \mathrm{H}\right]$ leucine $\mathrm{ml}^{-1}$ (final specific activity $=65.6-103.9 \mathrm{mCi} \mathrm{mmol}^{-1}$ ), and $2 \mu \mathrm{Ci}$ $\left[{ }^{14} \mathrm{C}\right.$ |galactose $\mathrm{ml}^{-1}$ (final specific activity $=0.358-0.430 \mathrm{mCi}$ $\left.\left.\mathrm{mmol}^{-1}\right)\right]$ was added. The $\mathrm{OD}_{420}$ was monitored and every hour $1.0 \mathrm{ml}$ samples of the labelling culture were precipitated with $1.0 \mathrm{ml}$ cold $10 \%(\mathrm{w} / \mathrm{v})$ TCA containing leucine and galactose (each at $1 \mathrm{mg} \mathrm{ml}^{-1}$ ), divided for duplicate measurements, and incubated on ice for $40 \mathrm{~min}$. Samples were filtered onto glass fibre filters (Whatman GF/F) and washed three times with $5 \%$ TC $A$ containing leucine and galactose (each at $1 \mathrm{mg} \mathrm{ml}^{-1}$ ), once with $95 \%(\mathrm{v} / \mathrm{v})$ ethanol, and counted for TCA-precipitable incorporated radioactive counts as described above.

Pulse double radiolabelling of glucan and protein. Sc488-11 A master cultures $(10 \mathrm{ml})$ were grown as above. The appropriate drug concentrations (see Figs 1a, 2 and 3) of cilofungin, papulacandin $\mathrm{B}$ and cycloheximide, respectively, were added at
$\mathrm{OD}_{420}=1 \cdot 0$. Samples $(1 \cdot 5 \mathrm{ml})$ of the cultures were pulselabelled for $40 \mathrm{~min}$ (approximately 0.3 of a cell generation) beginning at 10,40 and $70 \mathrm{~min}$ post drug addition. Prior to each labelling, $1.5 \mathrm{ml}$ of each master culture was removed to a $15 \mathrm{ml}$ flask in a shaking water bath. At the designated labelling start time, labelling mix (see above) was added to individual $15 \mathrm{ml}$ flasks. Following a 40 min labelling period, $1.0 \mathrm{ml}$ of each $1.5 \mathrm{ml}$ labelled culture was precipitated and duplicates counted as described above. The ratio of $\left[{ }^{14} \mathrm{C}\right]:\left[{ }^{3} \mathrm{H}\right]$ was calculated for analysis of inhibitor specificity.

Cell wall glucan release. Sc488-11 A cultures $(2 \mathrm{ml})$ were grown to a mid-exponential $\mathrm{OD}_{420}=2.5$ (before glycogen accumulation) containing labelling mix $\left[250 \mu \mathrm{Ci}\left[{ }^{3} \mathrm{H}\right]\right.$ galactose $\mathrm{ml}^{-1}$ and $1.0 \mathrm{mg}$ galactose carrier $\mathrm{ml}^{-1}$ (final specific activity $=23.7$ $\left.\left.47 \cdot 4 \mathrm{mCi} \mathrm{mmol}^{-1}\right)\right]$. The culture was washed three times with medium by centrifugation or with warmed medium by filtration. The cell pellet was resuspended $1: 10\left(\mathrm{OD}_{\mathbf{4 2 0}}=0 \cdot 25\right)$ in fresh low glucose YNB medium $(1 \times$ YNB with amino acids + $\left(\mathrm{NH}_{4}\right)_{2} \mathrm{SO}_{4}$ containing $0.4 \%$ glucose and $40 \mu \mathrm{g}$ adenine $\mathrm{ml}^{-1}$ ) without label. Immediately, $1 \mathrm{ml}$ of the culture was pelleted and $0.5 \mathrm{ml}$ of the supernatant counted in a scintillation counter (time $0)$. The $\mathrm{OD}_{420}$ was monitored and $0.5 \mathrm{ml}$ of the supernatant counted as before each hour after washing. At roughly $\mathrm{OD}_{420}=1.0$ the cells were pelleted, the supernatant removed, heated to $80^{\circ} \mathrm{C}$ for $5 \mathrm{~min}$ and adjusted to neutral $\mathrm{pH}$ (supernatant 1). The remaining pellet was resuspended in the original volume of fresh low glucose medium and growth continued until $\mathrm{OD}_{420}=$ approx. 3.0. The supernatant was harvested as before (supernatant 2). The final pellet was resuspended in twice the original volume of growth medium ( $2 \%$ glucose), grown overnight for additional release of labelled material, and processed as before (supernatant 3). Supernatants $(2 \mathrm{ml})$ were analysed by Bio-Gel P2 (Bio-Rad) column chromatography for liberated radiolabelled material. The remaining supernatants were lyophilized and saved for reutilization and digestion experiments (see below). Additionally, a labelled culture was monitored for growth and radiolabel release to obtain a kinetic profile for radiolabel release. A portion of this culture was also washed as above and resuspended in an equal volume of fresh medium to further demonstrate a second release of radiolabelled material.

Analysis of released material. The radioactive material released in supernatant 2 was digested with zymolyase $100 \mathrm{~T}$ (approx. 100 units) overnight at $30^{\circ} \mathrm{C}$ with rotation. Sodium azide $(0.02 \%)$ was included to inhibit growth of any contaminating organisms. The digested supernatant 2 and each of the three undigested supernatants were analysed by Bio-Gel P2 size exclusion column chromatography. Two columns $(0.7 \times 30 \mathrm{~cm}$ and $1.5 \times 50 \mathrm{~cm})$ packed with Bio-Rad P2 size exclusion chromatographic resin hydrated in water were connected in series, equilibrated with $0 \cdot 01 \mathrm{M}$ ammonium acetate, $\mathrm{pH} 5 \cdot 6$. Individual samples $(2 \mathrm{ml})$ of supernatant 1, 2 (before and after digestion) and 3 were loaded and fractions approximately $0.25 \mathrm{ml}$ in size were collected. Fractions were counted as before and the sample profiles compared to profile standards of $\left[{ }^{14} \mathrm{C}\right]$ glucose and $\left[{ }^{3} \mathrm{H}\right]$ laminaribiose. $\left[{ }^{14} \mathrm{C}\right]$ Glucose $(\sim 40000$ d.p.m.) was added to supernatants 2 and 3 as an internal control.

Reutilization of released material. A portion of supernatant 2 was lyophilized and resuspended in water. Approximately 7000 d.p.m. in $1 \mathrm{ml}$ water were added to an unlabelled $2 \mathrm{ml}$ culture $(2 \%$ glucose $)$ of $\mathrm{Sc} 488-11 \mathrm{~A}$ and grown to $\mathrm{OD}_{420}=$ approx. 3.0 . A sample $(0.5 \mathrm{ml})$ of the culture was TCAprecipitated and counted as described above.

Laminaribiose transport. Sc488-11A was grown at $32{ }^{\circ} \mathrm{C}$ in YPAD to $\mathrm{OD}_{420}=1 \cdot 0$. Cells were harvested by centrifugation $(10000 \mathrm{~g}, 10 \mathrm{~min})$, then washed twice with transport buffer 
containing $0 \cdot 1 \%$ glucose (Capobianco et al., 1993). Cells were resuspended in transport buffer at one-tenth the original volume. Cell suspensions were mixed with an equal volume of $\left[{ }^{3} \mathrm{H}\right]$ laminaribiose $(0.01 \mu \mathrm{Ci}$ at two specific activities, 0.6 or $60 \mathrm{mCi} \mathrm{mmol}^{-1}$, giving external concentrations of $85 \mu \mathrm{M}$ and $8.5 \mathrm{mM}$ total laminaribiose, respectively) at $32^{\circ} \mathrm{C}$ for $0,5,10$ and $20 \mathrm{~min}$. Cells were separated from the transport buffer by centrifugation through silicone oil as previously described (Capobianco et al., 1993). Cells were measured for uptake of radioactive counts.

Growth on laminarioligosaccharides. A $5 \mathrm{ml}$ starter culture of $\mathrm{Sc} 488-11 \mathrm{~A}$ was grown in $\mathrm{YNB}$ growth medium containing $2 \%$ glucose and $40 \mu \mathrm{g}$ adenine $\mathrm{ml}^{-1}$ to an $\mathrm{OD}_{420}=1.0$ in a shaking $30{ }^{\circ} \mathrm{C}$ water bath. Individual test cultures $(1 \mathrm{ml})$ were inoculated to a starting $\mathrm{OD}_{420}=0.05$ in YNB medium lacking glucose or supplemented with glucose (G1), laminaribiose (G2), laminarihexaose (G6) or laminarin (each at $10 \mathrm{mg} \mathrm{ml}^{-1}$ ), respectively. Duplicate cultures were grown in the presence of two glucanase inhibitors, deoxynojirimycin $\left(10 \times \mathrm{IC}_{50}=1.13 \mathrm{mM}\right)$ and castanospermine $\left(10 \times \mathrm{IC}_{50}=16 \mu \mathrm{M}\right)$. Growth of each culture was monitored over several days. Maximal growth yields and growth rate were reported qualitatively as compared to G1.

\section{RESULTS AND DISCUSSION}

\section{Strain construct and analysis of $\left[{ }^{14} \mathrm{C}\right]$ galactose labelling}

In the present study a genetic construct of $S$. cerevisiae was utilized to evaluate yeast cell wall synthesis and metabolism. Based on the construct phenotype, galactose is

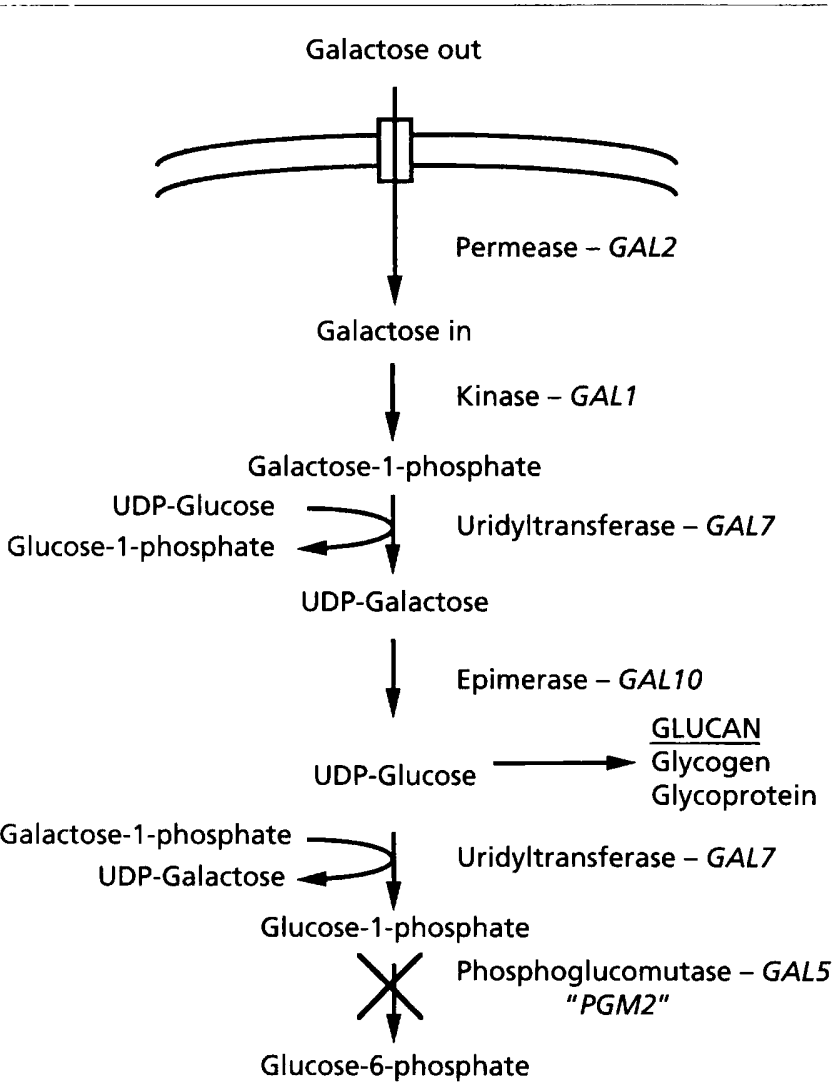

Fig. 1. Galactose metabolism in S. cerevisiae Sc488-11A. constitutively utilized in the presence of glucose and is preferentially incorporated into cell wall glucan. A deletion in the GAL80 regulatory gene allows constitutive expression of the genes necessary for galactose utilization (Nehlin et al., 1991; Yun et al., 1991). Galactose utilization is also not subject to glucose repression due to insertional inactivation of the major hexokinase PII isozyme (bxk2::UR A3) (Rose et al., 1991; Gancedo, 1992). Briefly, galactose is transported via a specific permease, phosphorylated, converted to UDP-galactose, and epimerized to UDP-glucose. The resulting UDPglucose is then incorporated into glucan without further dissemination through the glycolytic pathway. Further dissemination is prevented by the inactivation of the GAL5 gene (gal5::LEU2) encoding the major phosphoglucomutase (PGM2) isozyme (Bevan \& Douglas, 1969; Oh \& Hopper, 1990). UDP-glucose arising from glucose continues to be incorporated into glucan as a result of the activity of a minor PGM isozyme which converts glucose6-phosphate to glucose-1-phosphate (Fig. 1).

The incorporation of $\left[{ }^{14} \mathrm{C}\right]$ galactose into glucan and other macromolecules was assessed to verify the specificity of labelling in this particular construct. Following a continuous labelling period, the buffer-insoluble cell wall pellet contained $86 \%$ of the total radioactive counts. Buffer-soluble radioactive counts $(14 \%$ of the total cellassociated counts) likely arise from unincorporated UDPglucose which is not chased into product. Additionally, some of the counts may be due to small glucan fragments. A small amount of radiolabelled material $(9.5 \%$ of the total cell-associated counts) was released when the insoluble cell wall pellet was boiled with SDS. This may be a result of small glucan oligomers covalently attached to the mannan (Peberdy, 1990). The majority of radioactive counts $(60 \%$ of the total cell-associated counts) in the insoluble cell walls were released by zymolyase digestion. Zymolyase is a crude mixture of $(1,3)-\beta$-glucan laminaripenta-hydrolase, $(1,3)-\beta$-exoglucanase, proteinase and mannanase. Prolonged incubation of $(1,3)-\beta$ glucan (as laminarin) with zymolyase $100 \mathrm{~T}$ results in nearly complete hydrolysis to glucose (data not shown). Sephadex G-25 separation of the zymolyase-solubilized radiolabel resulted in two major peaks. One peak contained predominantly glucose plus small $(1,3)-\beta$ oligomers ( $70 \%$ of the zymolyase-solubilized label) as confirmed by thin layer chromatography. A second peak of larger undigestible oligomers contained $(1,6)-\beta$ linkages $(30 \%$ of the zymolyase-solubilized label). Qualitatively, this distribution is consistent with previous findings (Surarit $\&$ Shepherd, 1987). Minimal amounts of label $(1 \cdot 1 \%$ of the total cell-associated counts) were found in glycogen, digested with $\alpha$-amylase, which may be from a low constitutive level of glycogen biosynthesis (GSY1 = glycogen synthase 1) (Farkas et al., 1991). During late exponential growth, however, activation of the major glycogen synthase (GSY2) results in a rapid accumulation of radiolabel (data not shown). A small amount $(1.4 \%$ of the total cell-associated counts) of radiolabel was released by proteinase $\mathrm{K}$ digestion. Owing to the slow growth rate of this construct and the cellular 

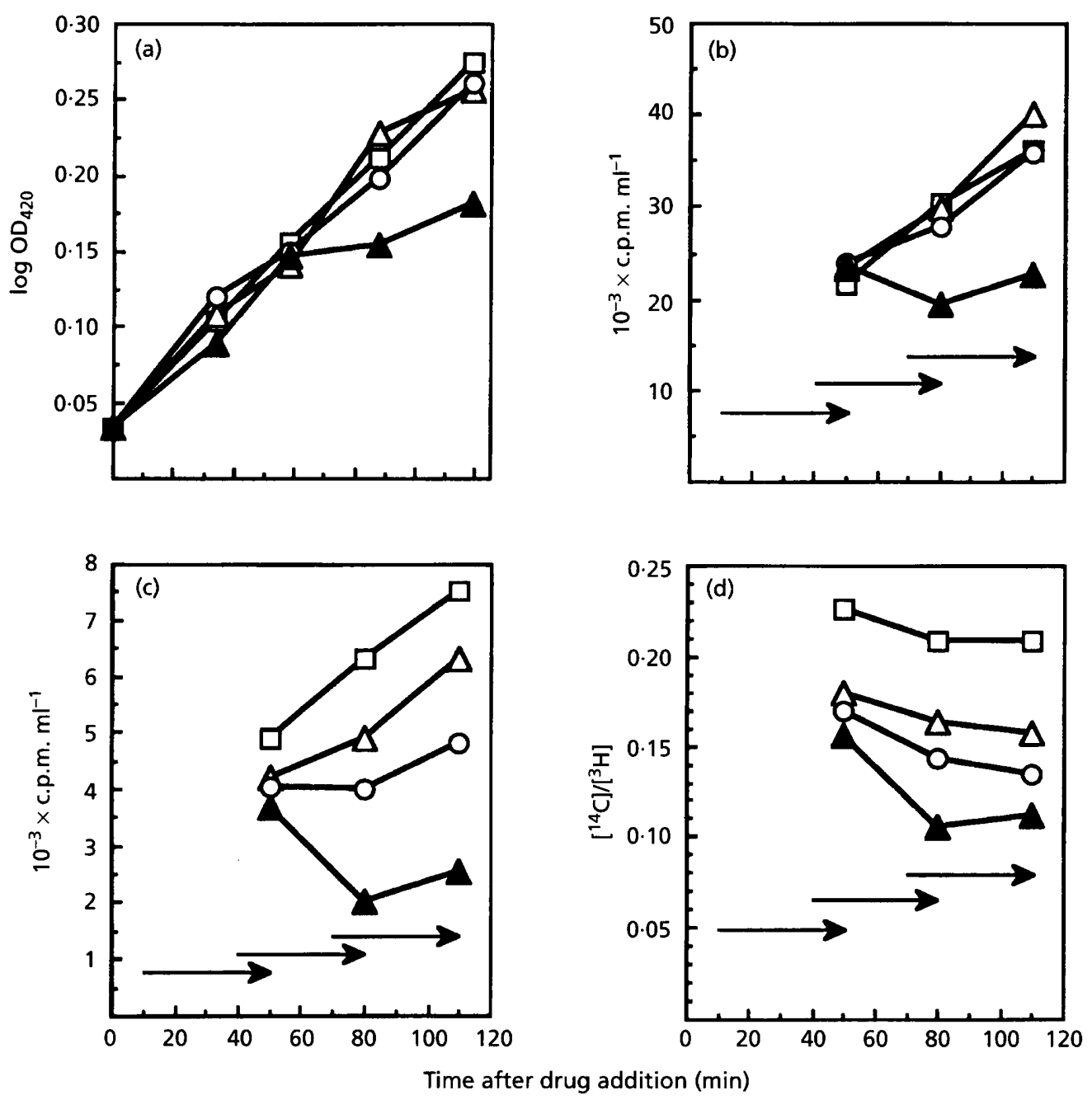

Fig. 2. Effects of cilofungin ( $\mu \mathrm{g} \mathrm{ml}^{-1}: \square, 0 ; \triangle, 50 ; 0,100 ; \Delta, 200$ ) on $S$. cerevisiae Sc488-11A growth (a), rate of ps (b), rate of gs (c) and ratio of gs to ps (d). Arrows indicate $40 \mathrm{~min}$ labelling period.

UDP-glucose pool, with which the radiolabel must equilibrate, a labelling period of approximately $0 \cdot 3$ generations (40 min) was indicated for pulsed-label analysis.

\section{Lack of glycogen accumulation below $\mathrm{OD}_{420}=3$}

Continuous labelling was performed to demonstrate the growth range in which this construct can be utilized for double labelling experiments without radiolabel dissemination into the glycogen biosynthetic pathway. Continuous $\left[{ }^{3} \mathrm{H}\right]$ leucine incorporation into TCA-precipitable cellular protein paralleled the exponential growth curve reaching near-stationary phase growth $\left(\mathrm{OD}_{420}=8\right)$ (data not shown). $\left[{ }^{14} \mathrm{C}\right] \mathrm{Galactose}$ incorporation into TCAprecipitable glucan displayed linear incorporation until $\mathrm{OD}_{420}=$ approx. 3 when incorporation markedly increased due to radiolabel accumulation into glycogen. Plotting the ratio of $\left[{ }^{14} \mathrm{C}\right]$ to $\left[{ }^{3} \mathrm{H}\right]$ initially yielded a zero slope indicating equal rates of glucan and protein synthesis. At $\mathrm{OD}_{420}=$ approx. 3 the labelling culture demon- strated a rapid elevation of $\left[{ }^{14} \mathrm{C}\right]$ galactose incorporation into glycogen causing the ratio to progressively increase (data not shown). It was concluded that specific double labelling can be performed confidently until midexponential phase growth $\left(\mathrm{OD}_{420}=3\right)$ with the majority of radioactive material accumulating in the cell wall glucan.

\section{Effect of inhibitors of glucan and protein synthesis}

Pulse double labelling of cell wall glucan and cellular protein was performed in the presence of specific inhibitors. The antifungal agent, cilofungin, had no apparent effect on growth (Fig. 2a) or $\left.{ }^{3} \mathrm{H}\right]$ leucine incorporation into total protein (Fig. 2b) until $200 \mu \mathrm{g} \mathrm{ml}^{-1}$ $(4 \times \mathrm{MIC})$. However, $\left[{ }^{14} \mathrm{C}\right]$ galactose incorporation into glucan decreased in a dose-dependent manner (Fig. 2c). While glucan and protein were both affected, the rate at which these two parameters were affected was unequal resulting in a decreased ratio of glucan to protein (Fig. $2 \mathrm{~d})$. The decreased ratio indicates a faster and more drastic 


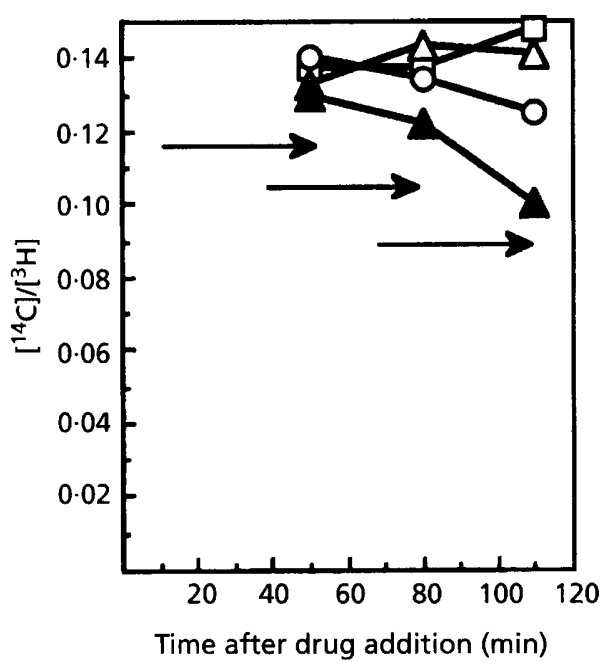

Fig. 3. Effects of papulacandin $B\left(\mu \mathrm{g} \mathrm{ml}^{-1}: \square, 0 ; \triangle, 1.0 ; 0,2.0\right.$; $\Delta, 4.0$ ) on the ratio of glucan to protein. Arrows indicate $40 \mathrm{~min}$ labelling period.

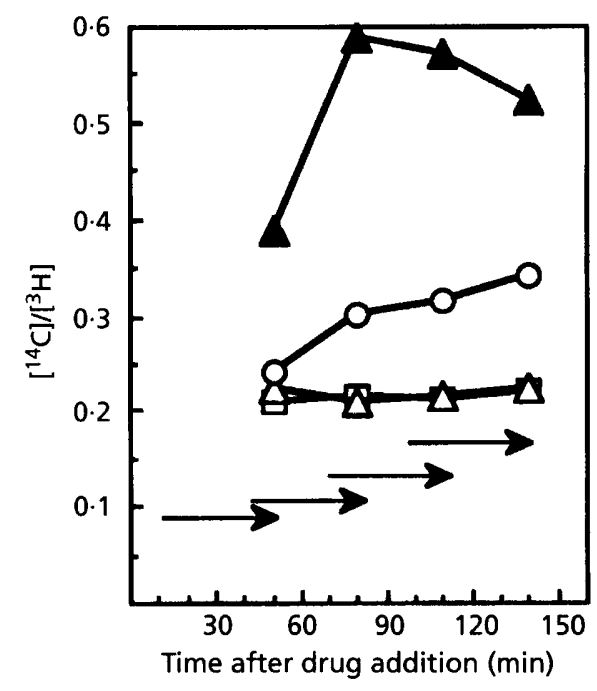

Fig. 4. Effects of cycloheximide $\left(\mu \mathrm{g} \mathrm{ml}^{-1}: \square, 0 ; \triangle, 0.004 ; 0\right.$, $0.02 ; \Delta, 0.10)$ on the ratio of glucan to protein. Cell growth, ps and gs display a dose-dependent decrease. Arrows indicate $40 \mathrm{~min}$ labelling period.

decrease in the rate of glucan synthesis compared to protein synthesis. This suggests that the effects on protein synthesis are secondary to that of glucan.

The antifungal agent, papulacandin B, demonstrated a slightly different profile than cilofungin. Cell growth displayed a dose-dependent decrease different from that observed with cilofungin (data not shown). Decreases in glucan and protein synthesis appeared to be affected at similar rates at low doses, and only at the highest concentration $\left(4 \mu \mathrm{g} \mathrm{ml}^{-1}=1.6 \times \mathrm{MIC}\right)$ was a clearly decreased glucan to protein ratio observed (Fig. 3 ). This may indicate that papulacandin $\mathrm{B}$ has other toxic effects on the yeast cell which affect protein synthesis and that there is less of a selectivity for glucan synthesis than cilofungin.

The effects of cycloheximide were assessed to demonstrate the specificity and selectivity of this construct and help validate this construct as having the ability to discriminate between specific effectors of gs and ps. Cycloheximide, a known inhibitor of ps, caused an increase in the ratio of glucan to protein (Fig. 4). This is an opposite effect of that observed with cilofungin and papulacandin B. Growth was decreased in a dose-dependent manner, as were gs and ps (data not shown). However, with complete inhibition of $\mathrm{ps}, \mathrm{OD}$ and gs increased slightly for a brief period. This further supports findings of continued gs with inhibition of ps (Elorza \& Sentandreu, 1969). This suggests that the decrease in gs is secondary to the inhibition of ps and that thickening of the glucan layer may result in an apparent continued growth when measured by OD.

Analysis of the ratio of rates of ps to gs by dual pulse labelling allowed discrimination of inhibitor specificity. To the best of our knowledge this is the first definitive study utilizing pulsed rate analyses. Previous labelling experiments by Tkacz (1984) were performed using a pgm2 (gal5) glc1 GAL81-12 GAL82-R1 strain which was obtained by traditional genetic crosses; however, all glucan labelling experiments were continuous, and incorporation was not normalized to any other parameter (e.g. dry weight, protein, OD, etc.). Thus, the experimental data on the effects of aculeacin A and cycloheximide were difficult to interpret. This strain was not available for comparative studies. Our strain construction differed in that constitutive expression of the genes involved in utilization of galactose was obtained by gene inactivation and deletion. As with any double labelling procedure, certain limits exist for the discrimination between inhibitor modes of action, in that any massive perturbation of macromolecular synthesis will have profound effects on all cellular processes given enough time (i.e. cell growth will cease). Acknowledging this fact, our system can differentiate between inhibitors based on their specificity of action by analysis of the ratio of the rates of incorporation of galactose and leucine. Inhibitors of gs cause this ratio to decrease, while a ps inhibitor caused an increase. This may indicate that gs and ps are not tightly coupled. It should be stressed that the glucan to protein ratio should not be the sole criterion for establishing specificity. Complete data analysis could elucidate potential mechanistic differences between compounds which may impair, for example, transport of radiolabelled material (unpublished observations).

\section{Kinetics and analysis of radiolabelled glucan release}

Prelabelled yeast cells, washed and diluted into fresh medium, shed cell wall glucan fragments into the surrounding medium demonstrating that the cell wall is subject to metabolic flux. Cells displayed a 2-3 h lag period after washing before exponential growth was resumed. Interestingly, during this lag period of apparently little growth, radiolabelled glucan fragments $(13.2 \%$ of the total cell-associated counts) were released into the 

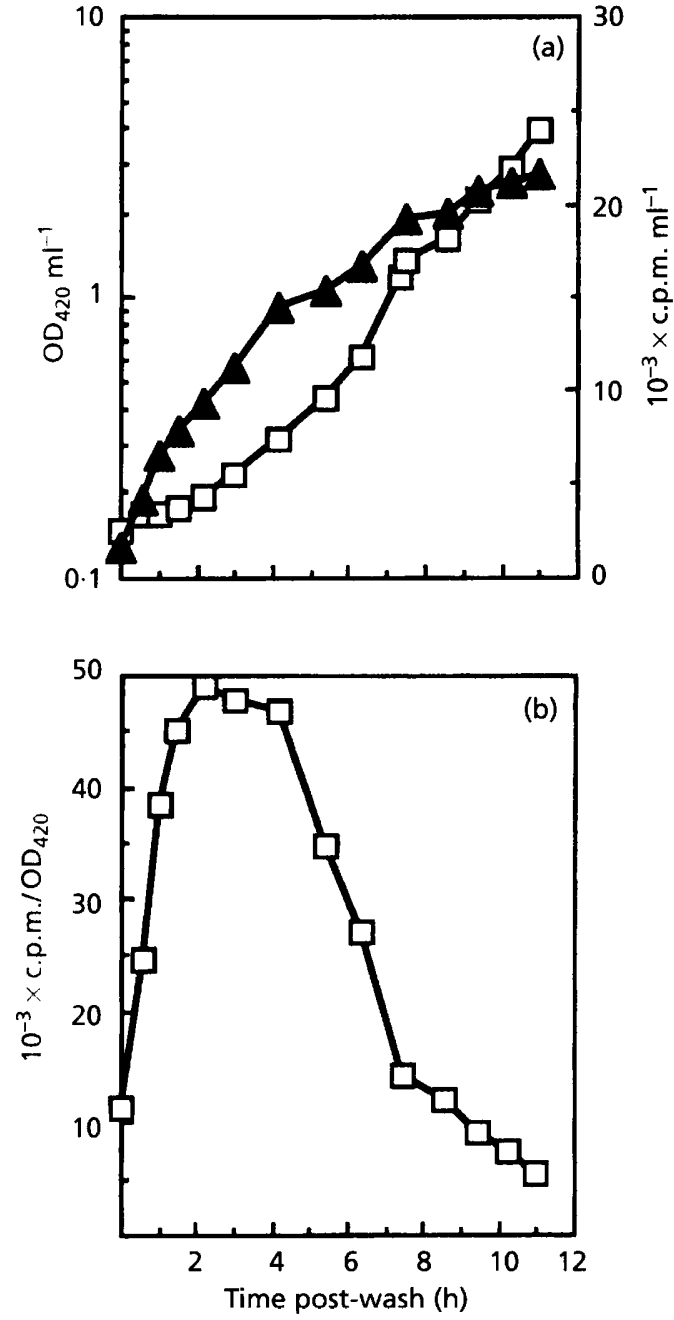

Fig. 5. (a) Release of radiolabelled cell wall glucan from prelabelled cells washed free of unincorporated label. A postwash lag period of $2 \mathrm{~h}$ corresponded to release of radiolabel (13.2\% of the total cell-associated counts) into the surrounding medium. An additional $17 \cdot 1 \%$ of the total cell-associated counts $(56.5 \%$ of the released radiolabel) were released after the cells had recovered and resumed exponential growth. $\square$, $\mathrm{OD}_{420}$; $\boldsymbol{\Lambda}$, radioactivity, (b) Glucan release per cellular mass displays a peak of released radiolabel concurrent with the resumption of exponential growth.

medium. A portion of this release might be induced by the washing procedure. However, an additional $17 \cdot 1 \%$ of the total cell-associated counts $(56.5 \%$ of the released radiolabel) were released after the cells had recovered and resumed exponential growth (Fig. 5a). Washing by filtration with warmed medium yielded similar results. The amount of released radiolabel per mass of cells peaked at the time in which the cells resumed exponential growth (Fig. 5b). By approximately $10 \mathrm{~h}$ post wash, the amount of released material reached an apparent maximum level. Upon overnight incubation, during which time the cells reached stationary phase $\left(\mathrm{OD}_{420}>10\right)$, the amount of radiolabel remained relatively unchanged from the $10 \mathrm{~h}$ measurement.

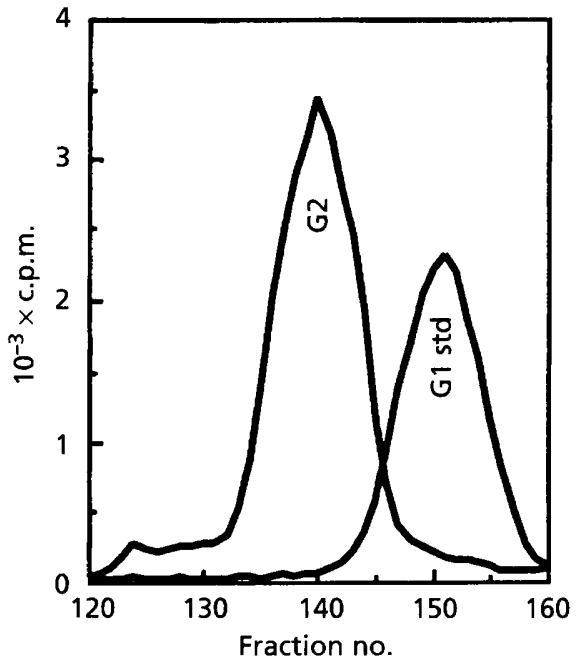

Fig. 6. Bio-Gel P2 size exclusion separation of supernatant 2 from cells prelabelled and washed free of unincorporated label.

The supernatant of an actively growing culture, previously washed free of any unincorporated radiolabel, was harvested at three time points and analysed for any released radiolabel by Bio-Gel P2 chromatography. Supernatant 1 (collected after two cell doublings) contained one peak comigrating with that of a radiolabelled disaccharide (laminaribiose) standard and a second peak with that of a glucose standard (data not shown). The second peak, owing to the loss of this peak in subsequent supernatants 2 and 3, was thought to contain a small amount of residual galactose or glucose possibly released from the cell during washing. A small peak (less than $1.5 \%$ of the total cell-associated counts) of high molecular mass material was observed only in supernatant 1 which was likely to be larger fragments of glucan. Supernatant 2 (collected after an additional threefold increase in cell density) contained only one major peak (G2) comigrating with that of a disaccharide standard and eluting ahead of a glucose standard (G1 std) (Fig. 6). Zymolyase digestion of this peak resulted in a shift to the right corresponding with a glucose standard, demonstrating that it contained $\beta-(1,3)$ linkages (data not shown). Quantitatively, the amount of released material was sequentially less over the course of cell growth: $14 \cdot 1-24 \cdot 4 \%$ of the total cellassociated counts (cells + medium) appeared in supernatant 1 (culture $\mathrm{OD}_{420}=1 \cdot 0$ ) of which $8.5-12.1 \%$ of the total cell-associated counts comigrated with a laminaribiose standard; supernatant 2 (culture $\mathrm{OD}_{420}=3 \cdot 0$ ) contained $3 \cdot 7-6.4 \%$ of the total cell-associated counts with $2 \cdot 9-4 \cdot 1 \%$ of the total cell-associated counts as laminaribiose; supernatant 3 (culture $\mathrm{OD}_{420}>8$ ) contained $2 \cdot 1-2 \cdot 9 \%$ of the total cell-associated counts with $1 \cdot 3-1 \cdot 7 \%$ of the total cell-associated counts as laminaribiose. The total amount of released radiolabel agrees with the kinetic release analysis demonstrated above.

Radiolabel shed by actively growing cells can be reutilized 
by yeast cells growing on glucose and is incorporated into TCA-precipitable material. However, the amount of incorporated material is only $3-5 \%$ of the amount added to the growing culture. Laminaribiose does not appear to be transported as a disaccharide (data not shown). Based on the limit of detection, less than 3 pmol per reaction (culture $\mathrm{OD}_{420}=0.5$ or $1.3 \mu \mathrm{l}$ cell volume) was transported $(<2 \cdot 3 \mu \mathrm{M}$ internal laminaribiose at $85 \mu \mathrm{M}$ and $8.5 \mathrm{mM}$ external laminaribiose). However, Sc488-11. A does have the ability to grow on laminaribiose as the sole carbon source, apparently after its hydrolysis to glucose (see below). Growth on a number of $(1,3)$ - $\beta$-laminarioligosaccharides as the sole carbon source was demonstrated, although the time to reach the maximal density was dependent on the size of the oligosaccharide. For example, the glucose-grown culture attained maximal density in less than $24 \mathrm{~h}$ while laminaribiose, laminarihexaose, and laminarin required approximately $2,3-4$, and $4-5 \mathrm{~d}$, respectively. Growth on (1,3)- $\beta$-laminarioligosaccharides appeared to require functioning extracellular glucanases as demonstrated by the effects of deoxynojirimycin and castanospermine. These amino sugars act as competitive inhibitors with a variety of $\boldsymbol{x}$ and $\beta$-glucosidases, including, for example, fungal exo$\beta(1,6)$-glucanase (Winchester \& Fleet, 1992). These inhibitors prevented growth in cultures grown with oligosaccharide substrates but did not have any effect on the glucose-grown culture. Incorporation of laminaribiose (following hydrolysis) accounts for very little of the TCAprecipitable material presumably owing to competition for transport with the cold glucose in the media. A basal level of extracellular laminaribiose may be maintained which may serve some, as yet unidentified, regulatory or protective purpose (i.e. glucan regulation, osmoregulation, immunoregulation) (Ruiz-Herrera, 1992).

Analysis of culture supernatants revealed that laminaribiose is a major wall component released from growing cells. Although a portion of the released radiolabel may be the result of changes in the wall architecture induced by washing procedures, this release continues well after exponential growth is resumed. Interestingly, laminaribiose is produced as one of the in vitro products of a newly identified $34 \mathrm{kDa}$ wall-associated glucosyltransferase from C. albicans (Hartland et al., 1991) and more recently from $S$. cerevisiae (P. A. Sullivan, personal communication). This enzyme transfers a linear $(1,3)-\beta$ glucose oligomer to the non-reducing end of an acceptor $(1,3)-\beta$ oligomer with the concomitant release of $\mathrm{G} 2$ from the reducing terminus of the donor molecule. Initially believed to represent a branch point, recent NMR studies revealed an intrachain $(1,6)-\beta$ linkage ('kink') connecting the two (1,3)- $\beta$ oligomers (Yu et al., 1993). The release, during growth, of labelled laminaribiose from prelabelled yeast glucan is consistent with the in vitro functioning of such a glucosyltransferase, lending support to the hypothesis that the yeast wall is metabolically active. Other exo- $(1,3)-\beta$-glucanases and endo- $\beta$-glucanases have been described which release glucose, gentobiose and other oligosaccharides from glucan (Ruiz-Herrera, 1992). The role of such activities in wall biochemistry is unknown at present. Mutants defective in specific exoglucanase activities are viable demonstrating that the products of certain exoglucanase genes are not essential for growth under normal conditions (Pitson et al., 1993). However, effects on growth under non-laboratory conditions and on virulence of pathogenic strains have not been studied. One such viable mutant lacks the BGL2 gene product, initially believed to be an exoglucanase but now considered an endoglucanase (Mrsa et al., 1993). The SSG1 gene encodes a sporulation-specific $(1,3)$ - $\beta$-glucanase in $S$. cerevisiae (San Segundo et al., 1993). From our studies of laminaribiose release and progressive decrease in the amount of shed material over time, we may speculate that newly synthesized wall material is more prone to enzymic modification than older pre-existing glucan, which would presumably have already undergone such events. It is reported that newly-formed cell wall from Aspergillus hyphae is more susceptible to autolysis thus increasing its plasticity during growth (Gooday et al., 1992; Peberdy, 1990). Yet, with maturation, the sub-apical region has increased rigidity corresponding, presumably, to enzymic modification (Wessels et al., 1990). Cell wall restructuring and modification involve a variety of activities which likely have roles in processes including: cell wall growth and extension, morphological events (i.e. in response to environmental conditions or nutrient status), autolysis, reproductive processes, and yeast-to-mycelial transition (for reviews see Peberdy, 1990; Ruiz-Herrera, 1992; Wessels et al., 1990).

The ever increasing list of opportunistic fungal infections in recent years due to the increase and variety of immunocompromised patients has brought a need for better understanding of yeast cell wall biology. The unique structure of the cell wall and its importance for the maintenance of cellular integrity is clearly established in the fungal system. Fungal cell wall assembly is likely a continuous metabolically organized process made up of several intertwined and interconnected components; the importance and balance of these events need further elucidation.

\section{ACKNOWLEDGEMENTS}

We thank Dr Jim Hopper for providing yeast strains and plasmids and for technical assistance in the construction of Sc488-11A. We thank Dr Alan Hinnebusch for providing plasmid Ep146. We also thank Dorothy Zakula for technical assistance.

\section{REFERENCES}

Beaudouin, R., Lim, S.T., Steide, J. A., Powell, M., McKoy, J., Pramanik, A. J., Johnson, E., Wood-Moore, C. \& Lipke, P. (1993). Bleomycin affects cell wall anchorage of mannoproteins in Saccharomyces cerevisiae. Antimicrob Agents Chemother 37, 1264-1269.

Bevan, P. \& Douglas, H. C. (1969). Genetic control of phosphoglucomutase variants in Saccharomyces cerevisiae. $J$ Bacteriol 98, $532-535$.

Cabib, E., Roberts, R. \& Bowers, B. (1982). Synthesis of the yeast cell wall and its regulation. Ann Rev Biocbem 51, 763-793.

Cabib, E., Silverman, S. J., Shaw, J. A., Das Gupta, S., Park, H.-M., Mullins, J. T., Mol, P. C. \& Bowers, B. (1991). Carbohydrates as 
structural constituents of yeast cell wall and septum. Pure Appl Chem 63, 483-489.

Capobianco, J. O., Zakula, D., Coen, M. L. \& Goldman, R. C. (1993). Anti-Candida activity of cispentacin: the active transport by amino acid permeases and possible mechanisms of action. Biochem Biopby Res Commun 190, 1037-1044.

Chambers, R. S., Broughton, M. J., Cannon, R. D., Carne, A., Emerson, G. W. \& Sullivan, P. A. (1993). An exo- $\beta$-glucanase of Candida albicans: purification of the enzyme and molecular cloning of the gene. J Gen Microbiol 139, 325-334.

Elorza, M. V. \& Sentandreu, R. (1969). Effect of cycloheximide in yeast cell wall synthesis. Biochem Biophys Res Commun 36, 741-747.

Farkas, I., Hardy, T. A., Goebl, M. G. \& Roach, P. J. (1991). Two glycogen synthase isoforms in Saccharomyces cerevisiae are coded by distinct genes that are differentially controlled. $J$ Biol Chem 266, $15602-15607$

Fleet, G. H. \& Manners, D. J. (1976). Isolation and composition of an alkali-soluble glucan from the cell walls of Saccharomyces cerevisiae. J Gen Microbiol 94, 180-192.

Frost, D., Brandt, K., Capobianco, J. \& Goldman, R. (1992). A microsomal and permeabilized whole cell assay of $(1,3)-\beta$-D-glucan synthase from Candida albicans. Abstract F46. Annu Meet Am Soc Microbiol 92, 506.

Gancedo, J. M. (1992). Carbon catabolite repression in yeast. Eur J Biochem 206, 297-313.

Gooday, G. W., Zhu, W. Y. \& O'Donnell, R. W. (1992). What are the roles of chitinases in the growing fungus? FEMS Microbiol Lett 100, 387.392.

Gopal, P., Sullivan, P. A. \& Shepherd, M. G. (1984). Isolation and structure of glucan from regenerating spheroplasts of Candida albicans. / Gen Microbiol 130, 1217-1225.

Hartland, R. P., Emerson, G. W. \& Sullivan, P. A. (1991). A secreted $\beta$-glucan-branching enzyme from Candida albicans. Proc R Soc Lond B 246, 155 160 .

Hector, R. F. (1993). Compounds active against cell walls of medically important fungi. Clin Microbiol Rev 6, 1-20.

Hien, N. H. \& Fleet, G. H. (1983). Separation and characterization of six 1,3- $\beta$-glucanases from Saccharomyces cerevisiae. J Bacteriol 156, 1204-1213.

Ito, H., Fukuda, Y., Murata, K. \& Kimura, A. (1983). Transformation of intact yeast cells treated with alkali cations. $J$ Bacteriol 153, $163-168$.

Klebl, F. \& Tanner, W. (1989). Molecular cloning of a cell wall exo$\beta$-1,3-glucanase from Saccharomyces cerevisiae. J Bacteriol 171, 6259-6264.

Kurranda, M. J. \& Robbins, P. W. (1991). Chitinase is required for cell separation during growth of Saccharomyces cerevisiae. J Biol Chem 266, $19758-19767$.

Maniatis, T., Fritsch, E. F. \& Sambrook, J. (1982). Molecular Cloning: A Laboratory Manual. Cold Spring Harbor, NY: Cold Spring Harbor Laboratory.

Manners, D. J., Masson, A. J. \& Patterson, J. C. (1973a). The structure of a $\beta-(1-3)-D$-glucan from yeast cell walls. Biochem J 135, 19-30.

Manners, D. J., Masson, A. J., Patterson, J. C., Bjorndal, H. \& Lindberg, B. (1973b). The structure of a $\beta$-(1-6)-D-glucan from yeast cell walls. Biochem $J 135,31-36$.

Mrsa, V., Klebl, F. \& Tanner, W. (1993). Purification and characterization of the Saccharomyces cerevisiae Bgl2 gene product, a cell wall endo- $\beta$-1,3-glucanase. J Bacteriol 175, 2102-2106.
Nehlin, J. O., Carlberg, M. \& Ronne, H. (1991). Control of yeast GAL genes by MIG1 repressor: a transcriptional cascade in the glucose response. EMBO J 10, 3373-3377.

Oh, D. \& Hopper, J. E. (1990). Transcription of a yeast phosphoglucomutase isozyme gene is galactose inducible and glucose repressible. Mol Cell Biol 10, 1415-1422.

Peberdy, J. F. (1990). Fungal cell walls - a review. In Biocbemistry of Cell Walls and Membranes in Fungi, pp. 5-30. Edited by P. J. Kuhn, A. P. J. Trinci, M. J. Jung, M. W. Goosey \& L. G. Copping. Berlin: Springer-Verlag.

Pitson, S. M., Seviour, R. J. \& McDougall, B. M. (1993). Noncellulolytic fungal $\beta$-glucanases: their physiology and regulation. Enzymol Microbiol Technol 15, 178-192.

Rose, M., Albig, W. \& Entian, K. D. (1991). Glucose repression in Saccharomyces cerevisiae is directly associated with hexose phosphorylation by hexokinases PI and PII. Eur J Biochem 199, 511-518.

Ruiz-Herrera, J. (1992). Fungal Cell Wall: Structure, Synthesis and Assembly. Boca Raton: CRC Press.

San Segundo, P., Correa, J., Vasquez De Aldana, C. R. \& Del Rey, F. (1993). SSG1, a gene encoding a sporulation-specific $1,3-\beta$ glucanase in Saccharomyces cerevisiae. J Bacteriol 175, 3823-3837.

Shepherd, M. G., Surarit, R., Gopal, P. K. \& Sullivan, P. A. (1984). Cell wall metabolism of $C$. albicans: $\beta(1-3)$ and $\beta(1-6)$ glucan synthesis. In Microbial Cell Wall Syntbesis and Autolysis, pp. 73-83. Edited by C. Nombela. New York Elsevier.

Sietsma, J. H. \& Wessels, J. G. H. (1979). Evidence for covalent linkages between chitin and $\beta$-glucan in a fungal cell wall. $J$ Gen Microbiol 114, 99-108.

Sietsma, J. H. \& Wessels, J. G. H. (1981). Solubility of (1-3)- $\beta$-D/(1$6)-\beta$-D-glucan in fungal cell walls: importance of presumed linkage between glucan and chitin. J Gen Microbiol 125, 209-212.

Surait, R. \& Shepherd, M. G. (1987). The effects of azole and polyene antifungals on the plasma membrane enzymes of Candida albicans. J Med Vet Mycol 25, 403-413.

Surarit, R., Gopal, P. K. \& Shepherd, M. G. (1988). Evidence for a glycosidic linkage between chitin and glucan in the cell wall of Candida albicans. J Gen Microbiol 134, 1723-1730.

Tkacz, J. S. (1984). In vivo synthesis of $\beta$-1,6-glucan in Saccharomyces cerevisiae. In Microbial Cell Wall Synthesis and Autolysis, pp. 287-295. Edited by C. Nombela. New York: Elsevier.

Valentin, E., Herrero, E., Javier Paster, F. I. \& Sentandreu, R. (1984). Solubilization and analysis of mannoprotein molecules from the cell wall of Saccharomyces cerevisiae. J Gen Microbiol 130, 1419-1428.

Wessels, J. G. H., Mol, P. C., Sietsma, J. H. \& Vermeulen, C. A. (1990). Wall structure, wall growth and fungal morphogenesis. In Biochemistry of Cell Walls and Membranes in Fungi, pp. 81-95. Edited by P. J. Kuhn, A. P. J. Trinci, M. J. Jung, M. W. Goosey \& L. G. Copping. Berlin: Springer-Verlag.

Winchester, B. \& Fleet, G. W. J. (1992). Amino-sugar glycosidase inhibitors: versatile tools for glycobiologists. Glycobiology 2, 199-210.

Yu, L. P., Goldman, R., Sullivan, P., Walker, G. F. \& Fesik, S. W. (1993). Heteronuclear $\mathrm{nmr}$ studies of $\mathrm{C}$-13-labelled cell wall $\beta$ glucan oligosaccharides. J Biomolecular NMR 3, 429-441.

Yun, S. J., Hiraoka, Y., Nishizawa, M., Takio, K., Titani, K., Nogi, Y. \& Fukasawa, T. (1991). Purification and characterization of the yeast negative regulatory protein GAL80. J Biol Chem 266, 693-697.

Received 4 January 1994; revised 4 March 1994; accepted 21 March 1994. 